\title{
Bir Tuğla Üretim İşletmesi ve İlişsili Sektörlerin Karşılaştırmalı Finansal Analizi
}

\author{
Harun ÖĞÜNÇ ${ }^{1 *}$ \\ ${ }^{1}$ Asst. Prof. Dr., Burdur Mehmet Akif Ersoy University, Bucak Zeliha Tolunay School of Applied Technology \\ and Management, Department of Accounting and Financial Management, Burdur, Turkey
}

Geliş Tarihi/Received: 18.05.2019

Kabul Tarihi/Accepted: 26.08.2019
Doi: doi.org/10.31200/makuubd.567335

Araştırma Makalesi/Research Article

\section{ÖZET}

İnşaat sektörü, kendisine girdi sağlasın veya sağlamasın, birçok alanda mal ve hizmet üretimini önemli ölçüde etkileyen bir yapıya sahiptir. Dolayısıyla tuğla ve çimento gibi girdiler, inşaat sektöründeki dalgalanmalardan az veya çok etkilenmektedir. Çalışmamızda ele alınan tuğla üretim işletmesi de inşaat sektörüne girdi sağlamaktadır. $\mathrm{Bu}$ nedenle bir tuğla üretim işletmesinin 2014, 2015 ve 2016 yıllarına ait finansal verilerinden elde edilen oranlar ile "imalat işletmeleri, diğer metalik olmayan mineral ürünlerin imalatını yapan işletmeler, kilden inşaat malzemesi üreten işletmeler, inşaat sektörü ve bina inşaatı yapan işletmeler"e ait oranlar karşılaştırılmıştır.

Çalışmanın amacı, belirlenen yıllar içerisinde tuğla üretim işletmesine ait oranların ilişkili sektörlerdeki oranlarla ne düzeyde benzerlik gösterdiğinin belirlenmesidir. Karşılaştırma yapılırken oran analizine ait stok, kârlılık ve satışları esas alan bazı oranlar kullanılmıştır. Elde edilen bulgular sonucunda, incelenen tuğla üretim işletmesinin özellikle stoklar/dönen varlıklar oranı, faaliyet kârı/net satışlar oranı, brüt satış kârı/net satışlar oranı ve satılan malın maliyeti/net satışlar oranının karşılaştırılan sektör ve işletme gruplarından farklı bir seyir izlediği görülmüştür.

Anahtar kelimeler: Tuğla Üretim İşletmesi, İnşaat Sektörü, Finansal Analiz.

\section{Comparative Financial Analysis of A Brick Production Plant and Related Sectors}

\section{ABSTRACT}

* Sorumlu yazar/Corresponding author 


\section{$\ddot{O} \breve{g} \ddot{u} n c ̧, H$.}

The construction sector, whether or not it provides input, has a feature that significantly affects the production of goods and services in many areas. Therefore, inputs such as bricks and cement are more or less affected by fluctuations in the construction sector. The brick production enterprise which is discussed in our study also provides input to the construction sector. For this reason, the ratios obtained from the financial data of a brick production enterprise for 2014, 2015 and 2016 and the ratios of "manufacturing enterprises, enterprises manufacturing other non-metallic mineral products, enterprises producing clay construction materials, construction enterprises and building construction enterprises" were compared.

The aim of this study is to determine the similarity of the ratios of brick production enterprises with the ratios in the related sectors. Some ratios based on inventory, profitability and sales of ratio analysis were used in comparison. As a result of the study, it is observed that the brick production enterprise, especially stocks/current assets ratio, operating profit/net sales ratio, gross sales profit/net sales ratio and cost of goods sold/net sales ratio are different from the compared sectors.

Keywords: Brick Production Enterprise, Construction Sector, Financial Analysis.

\section{GIRİŞ}

Ülke kaynaklarının etkin kullanımı ve katma değer sağlayan üretim faaliyetlerinin yaygınlaşması, ekonomik bağımsızlık için temel gereksinimlerdendir. Ancak sadece "üretebilir" olmak, faaliyetlerin sürdürülebilirliği için yeterli olmamaktadır. Aynı zamanda kârlılık ve verimliliğin de sağlanması ve devam ettirilebilmesi gerekmektedir. Buna karşılık genel ekonomik durum ve sektörel durgunluk gibi bazı koşullar altında sadece kâr odaklı düşünmek yerine mevcut durumun korunması ve işletmenin sürekliliğinin sağlanması daha önemli bir hâl alabilmektedir. Dolayısıyla işletmeyi dış etkenlerden bağımsız düşünmek yerine özellikle içerisinde bulunduğu ve ilişkili olduğu sektörler ile birlikte değerlendirmek daha sağlıklı karar vermeye yardımcı olacaktır. Bu noktada işletmelerin değerlendirmeye tabi tutulması için borç ödeme gücü, kaynakların yapısı, faaliyet devir hızı ve kârlılıkla ilgili detaylı bir analize ihtiyaç duyulmaktadır ve oran analizi bu aşamada önemli bir ihtiyacı karşılamaktadır.

Çalışmamızda bir tuğla üretim işletmesine ait 2014-2015-2016 yıllarındaki finansal oranların, ilişkili sektörler olan "kilden inşaat malzemeleri imalatı yapan işletmeler”, "diğer metalik olmayan mineral ürünler imalatı yapan küçük ölçekli işletmeler”, "küçük ölçekli imalat 
işletmeleri”, “inşaat sektörü” ve "bina inşaatı yapan işletmeler”e ait oranlarla hangi ölçüde benzerlik gösterdiği ortaya koyulmaya çalışılmıştır. Bu kapsamda oran analizine ait stoklar/dönen varlılar oranı, alacak devir hızı, çalışma sermayesi devir hızı, maddi duran varlık devir hızı, net kâr/aktif toplam oranı, net kâr/net satışlar oranı, faaliyet kârı/net satışlar oranı, brüt satış kârı/net satışlar oranı ve satılan malın maliyeti/net satışlar oranı kullanılmıştır.

\section{MALİ ANALIZZ}

Bir işletmenin faaliyetleri, sadece işletme sahiplerini ilgilendirmekle kalmayıp işletme çalışanları başta olmak üzere tedarikçiler, müşteriler, finans kurumları ve devlet gibi çok sayıda tarafı doğrudan veya dolaylı bir şekilde etkilemektedir. İşletme faaliyetlerinin sonuçları olarak hazırlanan mali tablolar ise çoğu zaman ihtiyaca uygun ve anlaşılır bilgi ortaya koymakta yetersiz kalabilmektedir. Bu nedenle, mali analiz amaciyla kullanılan trend analizi, yatay analiz, dikey analiz ve oran analizi, işletmelerin mali durumunun daha net bir şekilde ortaya koyulmasını sağlayan yöntemler olarak karşımıza çıkmakta olup işletme yönetiminin geleceğe dair karar vermesi noktasında oldukça önemli bir rol üstlenmektedir.

Trend analizinde yıllar itibariyle mali tablo kalemlerinde ortaya çıkan değişim incelenebilmektedir. Dikey analizde mali tablonun aynı yıla ait verilerinin grup içerisinde veya aktif/pasif içerisinde yüzde olarak ne kadar paya sahip olduğu gözlenebilmektedir. Yatay analizde birbirini takip eden yıllarda mali tablo kalemlerindeki artış veya azalışlar gözlenebilmektedir. Oran analizinde ise birbiri ile ilişki kurulabilen mali tablo kalemlerinin oranlanması yoluyla ilgili yılda işletmenin borç ödeme gücü, faaliyet etkinliği, finansal durumu ve kârlılı̆̆ına ilişkin sonuçlar ortaya koyulabilmektedir.

Çalışmamızda stoklar/dönen varlılar oranı, alacak devir hızı, çalışma sermayesi devir hızı, maddi duran varlık devir hızı, net kâr/aktif toplam oranı, net kâr/net satışlar oranı, faaliyet kârı/net satışlar oranı, brüt satış kârı/net satışlar oranı ile satılan malın maliyeti/net satışlar oranı kullanılarak 2014-2016 döneminde, araştırma yapılan tuğla üretim işletmesinin, içerisinde bulunduğu imalat alt sektörleri, inşaat sektörü ve bina inşaatı gerçekleştiren işletmelerin oranlarıyla karşılaştırılması sağlanmıştır.

\section{LITERATÜR TARAMASI}

Mali analiz teknikleri; geçmiş dönem verileri, sektör ortalamaları ve standart oranlar kullanılarak işletmelerin kârlılık, verimlilik, borçlanma vb. durumlarını ortaya koymaktadır ve bu konuda yapılmış çalışmaların bazıları aşağıda sunulmuştur. 


\section{Öğ̈̈̈nç, $H$.}

Yurdakul ve İç (2003), Türkiye'deki otomotiv sanayiinde faaliyet gösteren ve İstanbul Menkul Kıymetler Borsası'nda (İMKB) işlem gören büyük ölçekli beş firmayı derecelendirmeyi amaçladığ çalışmada TOPSIS (Technique for Order Preference by Similarity to Ideal Solution) yöntemini kullanarak firma performansını ortaya koymaya çalışmıştır. Elde edilen bulgulara göre, firma başarısını ölçmek için önerilen modelin benzer büyüklüğe sahip firmalar için aynı kriterler uygulanması durumunda faydalı bir yaklaşım olduğu belirlenmiştir.

Gökçen (2004), mali tablo analizi üzerinde enflasyonun ne gibi etkilere sahip olduğu üzerinde durduğu çalışmada, mali analiz tekniklerini örneklerle açıklamış ve mali tablo analizinden anlamlı sonuçlar elde edilebilmesi için öncelikle mali tabloların enflasyon düzeltmesine tabi tutulması gerektiğini belirtmiştir.

Altaş ve Giray (2005), mali başarısızlık riski bulunan işletmelerin belirlenmesi için bir model geliştirmeyi amaçlamış ve bu amaçla tekstil sektöründe faaliyet gösteren İMKB'ye kayıtlı işletmelerin 2001 yılına ait bilançoları kullanılarak oran analizine tabi tutulmuştur. Elde edilen bulgulara göre tekstil sektöründe olup İMKB'de işlem gören işletmelerin mali başarısızlığa uğramalarında en önemli etkenin "likidite” olduğu ortaya koyulmuştur.

Özgülbaş vd. (2008) tarafından gerçekleştirilen çalışmada Türkiye Cumhuriyet Merkez Bankası'nın (TCMB) yayımladığı özel hastane sektörüne ait mali tablolardaki kalemler kullanılarak oran analizi ve trend analizi yapılmış ve bu sektörün finansal durumu belirlenmeye çalışılmıştır. Çalışmada ayrıca Mann-Whitney U testi ile finansal performansa etki eden faktörler üzerinde durulmuştur. Elde edilen sonuçlara göre stok devir hızı, performansı etkileyen bir yapıya sahip değilken banka kredilerinin payındaki değişimin işletme performansını etkilediği görülmüştür.

Dumanoğlu ve Ergül (2010), İMKB'de işlem gören ALCTL, ANELT, ARENA, ASELS, ESCOM, INDES, KAREL, LINK, LOGO, NETAS, PKART kodlu onbir teknoloji şirketinin mali tablolarını kullanarak 2006-2009 yılları arasında bu şirketlere ait mali performansları TOPSIS yöntemiyle analiz etmiş ve karşılaştırmıştır. Elde edilen bulgulara göre mali performans açısından en başarılı şirket 2006, 2007 ve 2008 yıllarında ARENA iken 2009 y1lında PKART olmuştur.

Uyar ve Okumuş (2010) tarafından gerçekleştirilen çalışmada İMKB'de işlem gören üretim işletmelerinin küresel ekonomik krizden etkilenme düzeylerinin finansal oranlar aracılığıyla ortaya koyulması amaçlanmış olup bu kapsamda likidite, varlık devir hızı, kârlılık 
oranları ve mali yapı oranlarının söz konusu işletmeler üzerindeki etkileri üzerinde durulmuştur. Elde edilen sonuçlara göre kriz döneminde işletmelerin likidite oranlarında, varlık devir hızlarında ve kârlılık oranlarında düşme gözlenirken stok devir hızı ve alacak devir hızında anlamlı bir farkın ortaya çıkmadığı, borçlanmada ise artış olduğu belirlenmiştir.

Akyüz vd. (2011), seramik sektöründe faaliyet gösteren ve İMKB'de işlem gören bir işletmenin 1998-2008 dönemindeki finansal performansını TOPSIS yöntemiyle değerlendirmiş ve işletmenin başarı durumu yıllar itibariyle ortaya koyulmuştur. Çalışma sonucunda en başarılı geçirilen yılın 2005, en başarısız geçirilen yılın ise 2003 olduğu ve yıllar itibariyle tutarlı bir gelişmenin gösterilemediği belirlenmiştir.

Özer (2012), eğitim ve araştırma hastanesi olarak faaliyet gösteren bir kuruma ait mali tabloları kullanarak oran analizi ve karşılaştırmalı tablolar analizi yöntemlerini uygulamıştır. Elde edilen sonuçlara göre 2008 ve 2009 yıllarında ticari alacakların tahsilinde sorun yaşandığı, 2008 yılında zarar eden hastanenin 2009 ve 2010 yıllarında kâra geçtiği belirlenmiştir.

Akın ve Ece (2013) tarafından gerçekleştirilen çalışmada İMKB'de işlem gören sigorta şirketleri ele alınmıştır. Söz konusu şirketlerin 2006-2010 dönemine ait finansal performanslarını ölçmek amacıyla oran analizi ve karşılaştırmalı tablolar analizi yöntemleri kullanılmıştır. Elde edilen bulgulara göre sigorta sektörü, finansal krizin etkilerini öngörebildiği için bu sektördeki şirketler piyasa değerini koruyabilmiştir.

Karadeniz vd. (2014), spor şirketlerini incelediği çalışmada Borsa İstanbul'da (BİST) işlem gören dört spor şirketinin verilerini kullanarak finansal performanslarını oran analizi yöntemiyle belirleyip bu şirketlerin iflas risklerini tespit etmeyi amaçlamıştır. Elde edilen bulgulara göre spor şirketleri finansal yükümlülüklerini yerine getirme konusunda sorunlarla karşılaşmakta olup varlıklarını etkin bir şekilde kullanamamakta ve Altman Z değeri sonuçlarına göre iflas riski taşımaktadırlar.

Akbulut ve Rençber (2015), BİST’te işlem gören imalat sektöründeki işletmeleri ele aldıkları çalışmada oran analizi ile TOPSIS yöntemlerini kullanarak bu işletmelerin finansal performanslarını ölçmeyi amaçlamıştır. Elde edilen sonuçlara göre işletmelerin finansal performansları ile borsa performansları arasında anlamlı bir ilişki bulunmamaktadır.

Selimoğlu ve Orhan (2015), finansal başarısızlığı ölçmeyi amaçladıkları çalışmada BİST’te işlem gören dokuma, giyim eşyası ve deri işletmelerine ait verileri kullanarak oran 


\section{Öğ̈̈̈nç, H.}

analizi ve diskriminant analizini uygulamıştır. Çalışma sonucunda başarılı ve başarısız işletmelerin belirlenmesi için kullanılan 23 finansal oran içerisinde 7 finansal oranın anlamlı farkl1l1k gösterdiği belirlenmiştir.

Demir ve Çelik (2015) tarafından ihracat yapan 882 firmaya ait verilerin incelendiği çalışmada, bu firmaların mali tabloları analiz edilerek TCMB tarafından yayınlanan analizlerle karşılaştırılmıştır. Elde edilen sonuçlara göre ihracatçı firmaların genel olarak banka kredilerine erişim düzeyinin daha iyi olduğu ve piyasa koşullarından daha az etkilendiği ortaya koyulmuştur.

Karadeniz vd. (2015), TCMB tarafindan yayınlanan finansal oranları kullanarak karayollarında yolcu taşımacılığı yapan işletmelere oran analizi yöntemini uygulamış ve söz konusu sektörün finansal durumunu yorumlamıştır. Çalışma sonucunda sektörün sabit varlık yatırımının ağırlıklı olduğu, likidite oranları açısından zayıf bir yapıya sahip olduğu, yabancı kaynak ağırlıklı olduğu için finansal riskinin yüksek olduğu, varlıklarını etkin şekilde kullanamadığı ve kârlılık oranları açısından negatif bir yapıya sahip olduğu ortaya koyulmuştur.

İskenderoğlu vd. (2015), enerji sektörünü ele aldıkları çalışmada TCMB tarafından yayınlanan sektör bilançolarından faydalanmıştır. Bu kapsamda Türkiye'deki enerji sektörü ile Avrupa enerji sektörüne ait mali analizi gerçekleştirmek için oran analizi yöntemini kullanmış ve sonuçları karşılaştırmıştır. Elde edilen bulgulara göre Avrupa enerji sektöründe faaliyet gösteren işletmelerin likidite, finansal yapı, verimlilik ve kârlılık açısından Türkiye enerji sektöründeki işletmelere göre daha iyi performans gösterdikleri ortaya koyulmuştur.

Karadeniz vd. (2016), konaklama sektörünü ele aldıkları çalışmada TCMB tarafından yayınlanan konaklama sektörüne ait mali tablo verilerini kullanmış olup 2012, 2013 ve 2014 yıllarında meydana gelen değişimleri işletme büyüklüklerine göre karşılaştırmalı tablolar analizi tekniğini kullanarak incelemişlerdir. Elde edilen sonuçlara göre sadece büyük ölçekli firmaların varlık-kaynak dengesine dikkat ettiği görülmüştür. Ayrıca genel yönetim gideri, finansman gideri ve kambiyo zararlarının küçük, orta ve büyük ölçekli işletmelerde kâr artışına engel olduğu ortaya koyulmuştur.

Hacıevliyagil ve Şit (2016), imalat sektörünü ele aldıkları çalışmada bu sektördeki firmaların finansal oranları arasında anlamlı bir farklılık olup olmadığını ortaya koymayı amaçlamış ve nakit oranı haricinde anlamlı bir farklılık olmadığı sonucuna ulaşmışlardır. 
İltaş (2016), TCMB tarafindan yayınlanan sektör bilançolarından faydalandığ çalışmada "işletme sermayesi gereksinimi ile nakde dönüşüm süresi, kaldıraç oranı, cari oran ve aktif kârlılığı arasında uzun dönemli eşbütünleşme ilişkisinin varlı̆̆g”nı tespit etmeye çalışmıştır. Çalışma sonucunda işletme sermayesi gereksinimi, nakde dönüşüm süresi, kaldıraç oranı, cari oran ve aktif kârlılı̆̆ı arasında uzun dönem eşbütünleşme ilişkisinin olduğu ortaya koyulmuştur. Ayrıca kaldıraç oranı ve cari oran arasında anlamlı bir ilişki tespit edilmiştir.

Özolgun (2017), mali analizin işletmeler için önemi üzerinde durduğu çalışmada karşılaştırmalı tablolar analizi yöntemini bir örnek ile açıklamış ve söz konusu yönteme göre ulaştığı sonuçları yorumlamıştır.

Ersöz (2017), bir üniversite ve bir büyükşehir belediyesini incelediği çalışmada mali tablo verilerini kullanarak kamu kurumlarında mali tablo analiz yöntemlerinin uygulanabilirliği üzerinde durmuştur. Elde edilen sonuçlara göre mali tablo analiz tekniklerinin kamu sektörüne ait mali tablolarda da uygulanabileceği; ancak özellikle oran analizi konusunda bazı idarelerin görev ve faaliyetleriyle uyumlu şekilde özel oranların belirlenip uygulanması gerektiği sonucuna varılmıştır.

Öğünç (2018), TCMB tarafından yayınlanan sektör istatistiklerinden gıda ve tekstil sektörlerine ait 2014, 2015 ve 2016 y1llarındaki mali bilgileri kullanarak küçük, orta ve büyük ölçekli işletmeler açısından söz konusu sektörleri oran analizi yöntemiyle karşılaştırmaya tabi tutmuştur. Elde edilen sonuçlara göre genel olarak küçük ölçekli işletmelerin daha olumsuz bir görünüme sahip olduğu ve gıda sektöründe borç ödeme güçlügü yaşandığı belirlenmiştir. Ayrıca tekstil sektöründe alacak tahsil süresinin uzun olması önemli bir sorun olarak görünmektedir.

Yapılan literatür araştırması sonucunda tuğla sektörü, inşaat sektörü ve imalat sektörünü bir arada değerlendirip finansal açıdan karşılaştıran herhangi bir çalışmaya ulaşılamaması nedeniyle bu çalışma önem arz etmekte olup literatürdeki eksikliğin kapatılmasına yardımcı olması beklenmektedir.

\section{ARAŞTIRMANIN AMACI, ÖNEMI VE KAPSAMI}

Bu çalışmada, Türkiye'de önemli bir ekonomik role sahip olan inşaat sektörünün temel girdilerinden biri konumundaki tuğlanın üretildiği bir işletmeye ait oranlar ile tuğla üretim işletmesinin dâhil olduğu "kilden inşaat malzemeleri imalatı yapan işletmeler", bir üst sektör 


\section{$\ddot{O} \breve{g} \ddot{u ̈ n c ̧, ~ H . ~}$}

olarak "diğer metalik olmayan mineral ürünler imalatı yapan küçük ölçekli firmalar", "küçük ölçekli imalat işletmeleri” ile "inşaat sektörü” ve "bina inşaatı işletmeleri”"ne ait oranların karşılaştırılıp yorumlanması amaçlanmaktadır.

Tuğla üretim işletmesi dışındaki veriler, TCMB tarafından düzenli olarak yayınlanan sektör bilançoları istatistiklerinden elde edilmiştir. Söz konusu veriler TCMB tarafindan yayınlanan mevcut son çalışma olması nedeniyle 2014-2016 dönemi çalışmada esas alınmıştır. Ayrıca sektör bilançolarındaki işletme sayısının ve dolayısıyla sektörlere ait mali verilerin kapsamının her dönemde farklılık arz etmesi nedeniyle önceki yıllara ait veriler çalışmaya dâhil edilmemiştir.

Gerçekleştirilen literatür taraması sonucunda tuğla sektörüne ait finansal oranların sözü edilen sektörlerle daha önce karşılaştırılmamış olması açısından bu çalışma önem arz etmekte olup, çalışmada sadece TCMB ile finansal bilgilerini paylaşan işletmelere ait verilerin yer alması, belirli yılları kapsaması ve belirli oranların kullanılması nedeniyle çalışmanın kapsamı sinırlı düzeydedir.

\section{ARAŞTIRMANIN UYGULANMASI}

TCMB ülke genelindeki imalat sektörlerine ve imalat dışı sektörlere ait yıllık mali tabloları 1990 yılından bu yana düzenli bir şekilde yayınlamak suretiyle geniş bir kullanıcı kitlesine düzenli ve kapsamlı bilgiler sunmaktadır. Ancak bu bilgilerin işletmelerden gönüllülük esasına dayalı olarak temin edilmesi nedeniyle söz konusu bilgilerin tüm sektörü kapsadığı söylenemez (www.tcmb.gov.tr).

10 milyon Euro'nun altında net satış tutarına sahip olan işletmeler küçük ölçekli işletme olarak dikkate alındığı için (http://www3.tcmb.gov.tr/sektor/2017/Raporlar/sunus.pdf), çalışmada karşılaştırmaya tabi tutulan tuğla üretim işletmesi küçük ölçekli işletme sınıfına dâhil olmaktadır. Dolayısıyla karşılaştırma kapsamında, ilgili sektör ve alt sektörlerdeki küçük işletmelere ait veriler esas alınmıştır.

Tuğla üretim işletmesi, imalat alt sektörleri içerisinde "C23: Diğer metalik olmayan mineral ürünlerin imalatı" içerisinde yer almaktadır ve bu sektörde toplam 272 firmaya ait mali tablo bilgisi kullanılmıştır (http://www.tcmb.gov.tr). C23 olarak sınıflandırılan bu kategoride yer alan alt gruplar Tablo 1'de sıralanmıştır. 
Tablo 1. C23: Diğer metalik olmayan mineral ürünlerin imalatı kapsamındaki üretim gruplar1

\begin{tabular}{|c|c|}
\hline $\mathrm{C} 23$ & Diğer metalik olmayan mineral ürünlerin imalatı \\
\hline 23.1 & Cam ve cam ürünleri imalatı \\
\hline 23.11 & Düz cam imalatı \\
\hline 23.12 & Düz camın şekillendirilmesi ve işlenmesi \\
\hline 23.13 & Çukur cam imalatı \\
\hline 23.14 & Cam elyafi imalatı \\
\hline 23.19 & Diğer camların imalatı ve işlenmesi (teknik amaçlı cam eşyalar dâhil) \\
\hline 23.2 & Ateşe dayanıklı (refrakter) ürünlerin imalatı \\
\hline 23.3 & Kilden inşaat malzemeleri imalatı \\
\hline 23.31 & Seramik karo ve kaldırım taşları imalatı \\
\hline 23.32 & Fırınlanmış kilden tuğla, karo ve inşaat malzemeleri imalatı \\
\hline 23.4 & Diğer porselen ve seramik ürünlerin imalatı \\
\hline 23.41 & Seramik ev ve süs eşyaları imalatı \\
\hline 23.42 & Seramik sıhhi ürünlerin imalatı \\
\hline 23.43 & Seramik yalıtkanların (izolatörlerin) ve yalıtkan bağlantı parçalarının imalatı \\
\hline 23.44 & Diğer teknik seramik ürünlerin imalatı \\
\hline 23.49 & Başka yerde sınıflandırılmamış diğer seramik ürünlerin imalatı \\
\hline 23.5 & Çimento, kireç ve alçı imalatı \\
\hline 23.51 & Çimento imalatı \\
\hline 23.52 & Kireç ve alçı imalatı \\
\hline 23.6 & Beton, çimento ve alçıdan yapılmış eşyaların imalatı \\
\hline 23.61 & İnşaat amaçlı beton ürünlerin imalatı \\
\hline 23.62 & İnşaat amaçlı alçı ürünlerin imalatı \\
\hline 23.63 & Hazır beton imalatı \\
\hline 23.64 & Toz harç imalatı \\
\hline 23.65 & Lif ve çimento karışımlı ürünlerin imalatı \\
\hline 23.69 & Beton, alçı ve çimentodan yapılmış diğer ürünlerin imalatı \\
\hline 23.7 & Taş ve mermerin kesilmesi, şekil verilmesi ve bitirilmesi \\
\hline 23.9 & Aşındırıcı ürünlerin ve başka yerde sınıflandırılmamış metalik olmayan mineral ürünlerin imalatı \\
\hline 23.91 & Aşındırıcı ürünlerin imalatı \\
\hline 23.99 & Başka yerde sınıflandırılmamış metalik olmayan diğer mineral ürünlerin imalatı \\
\hline
\end{tabular}

Kaynak: http://www.tcmb.gov.tr, 2018

Tablo 1'de sunulan sınıflandırmada bir alt grup olan "23.3: Kilden inşaat malzemeleri imalatı” içerisindeki “23.32: Fırınlanmış kilden tuğla, karo ve inşaat malzemeleri imalatı”, tuğla üretim işletmesinin yer aldığı grubu temsil etmektedir. Ancak 23.32 kodlu gruba ait verilere ulaşılamadığ 1 için tuğla üretim işletmesine ait veriler ile sektördeki diğer elde edilen veriler karşılaştırmaya tabi tutulmuştur. Bu kapsamda küçük ölçekli imalat işletmeleri, diğer metalik olmayan mineral ürünlerin imalatını yapan tüm işletmeler ve aynı gruba ait küçük işletmelere ait bazı bilgiler Tablo 2'de sunulmuştur. 
Tablo 2. Küçük ölçekli imalat ile diğer metalik olmayan mineral ürünlerin imalatını yapan işletmelere ait bazı bilgiler

\begin{tabular}{|c|c|c|c|c|c|c|}
\hline \multirow[t]{2}{*}{ Firma Özellikleri } & \multicolumn{2}{|c|}{$\begin{array}{l}\text { İmalat, Küçük } \\
\text { Ölçekli Firmalar }\end{array}$} & \multicolumn{2}{|c|}{$\begin{array}{l}\text { Diğer Metalik } \\
\text { Olmayan Mineral } \\
\text { Ürünlerin İmalatı }\end{array}$} & \multicolumn{2}{|c|}{$\begin{array}{l}\text { Diğer Metalik Olmayan } \\
\text { Mineral Ürünlerin } \\
\text { İmalatı, Küçük Ölçekli } \\
\text { Firmalar }\end{array}$} \\
\hline & Sayı & $\%$ & Sayı & $\%$ & Sayı & $\%$ \\
\hline İncelenen Firma Sayısı & 1467 & 100,0 & 272 & 100,0 & 160 & 100,0 \\
\hline Küçük Ölçekli Firmalar & 1467 & 100,0 & 160 & 58,8 & - & - \\
\hline Orta Ölçekli Firmalar & - & - & 77 & 28,3 & - & - \\
\hline Büyük Ölçekli Firmalar & - & - & 35 & 12,9 & - & - \\
\hline Anonim Şirket Sayısı & 694 & 47,3 & 162 & 59,6 & 78 & 48,8 \\
\hline Limited Şirket Sayısı & 773 & 52,7 & 110 & 40,4 & 82 & 51,3 \\
\hline Kâr Eden Firma Sayısı & 1002 & 68,3 & 198 & 72,8 & 115 & 71,9 \\
\hline Zarar Eden Firma Sayısı & 464 & 31,6 & 74 & 27,2 & 45 & 28,1 \\
\hline Kâr/Zarar Oluşmayan Firma Sayısı & 1 & 0,1 & - & - & - & - \\
\hline
\end{tabular}

Kaynak: http://www.tcmb.gov.tr, 2018.

Tablo 2 incelendiğinde küçük ölçekli 1467 imalat işletmesine ait verinin kullanıldığg, diğer metalik olmayan mineral ürünlerin imalatını yapan toplam 272 firma içerisinde 160 işletmenin küçük ölçekli olduğu ve bu işletmelerin söz konusu grup içerisinde yüzde 59 paya sahip olduğu görülmektedir.

Tuğla, inşaat sektörünün temel girdilerinden biri olması nedeniyle çalışmada inşaat sektörüne ait veriler de karşılaştırmaya tabi tutulmuş olup inşaat sektörü ve bina inşaatı sektörüne ait bazı bilgiler Tablo 3'te sunulmuştur.

Tablo 3. İnşaat ve bina inşaatı sektörlerine ait bazı bilgiler

\begin{tabular}{|l|r|r|r|r|}
\hline \multirow{2}{*}{\multicolumn{1}{|c|}{ Firma Özellikleri }} & \multicolumn{2}{|c|}{ Inşaat } & \multicolumn{2}{c|}{ Bina İnşaatı } \\
\cline { 2 - 5 } & \multicolumn{1}{c|}{ Sayı } & \multicolumn{1}{c|}{$\%$} & \multicolumn{1}{c|}{ Sayı } & \multicolumn{1}{c|}{ \% } \\
\hline İncelenen Firma Sayısı & 945 & 100,0 & 695 & 100,0 \\
\hline Küçük Ölçekli Firmalar & 408 & 43,2 & 307 & 44,2 \\
\hline Orta Ölçekli Firmalar & 341 & 36,1 & 247 & 35,5 \\
\hline Büyük Ölçekli Firmalar & 196 & 20,7 & 141 & 20,3 \\
\hline Anonim Şirket Sayısı & 497 & 52,6 & 368 & 52,9 \\
\hline Limited Şirket Sayısı & 446 & 47,2 & 325 & 46,8 \\
\hline Komandit Şirket & 1 & 0,1 & 1 & 0,1 \\
\hline Adi Komandit Şirket & 1 & 0,1 & 1 & 0,1 \\
\hline \hline Kâr Eden Firma Sayısı & 540 & 57,1 & 372 & 53,5 \\
\hline Zarar Eden Firma Sayısı & 402 & 42,5 & 320 & 46,0 \\
\hline Kâr/Zarar Oluşmayan Firma Sayısı & 3 & 0,3 & 3 & 0,4 \\
\hline
\end{tabular}

Kaynak: http://www.tcmb.gov.tr, 2018. 
Tablo 3 incelendiğinde inşaat sektöründe 945 işletmeye ve bina inşaatıyla ilgilenen 695 işletmeye ait bilginin elde edildiği ve bunlar içerisinde en yüksek paya inşaat sektöründe yüzde 43, bina inşaatı işletmelerinde ise yüzde 44 oranla küçük ölçekli işletmelerin sahip olduğu görülmektedir.

Kâr amacı olsun veya olmasın tüm işletmelerin mal veya hizmet satışı gerçekleştirmek amacıyla faaliyet gösterdiği bir gerçektir. Ancak mevcut varlıklarla ne ölçüde satış yapıldığg, satışların maliyeti ve nakde dönüşüm süresi, satışlar karşılığında ne kadar kâr elde edildiği ve elde edilen kârın ne kadarının esas faaliyetlerden elde edildiği gibi belirsizlikler, işletme yönetiminde önemli risk unsurları olarak karşımıza çıkmaktadır. Söz konusu belirsizlikler dikkate alınarak belirlenen oranlar, karşılaştırma yapmak amacıyla seçilmiş ve Tablo 4'te sunulmuştur.

Tablo 4. Hesaplamada kullanilan oranlar

\begin{tabular}{|l|}
\hline Stoklar / Dönen Varlıklar Oranı \\
\hline Alacak Devir Hızı = Net Satışlar / (Kısa Vadeli Ticari Alacaklar + Uzun Vadeli Ticari Alacaklar) \\
\hline Çalışma Sermayesi Devir Hızı = Net Satışlar / Dönen Varlıklar \\
\hline Maddi Duran Varlık Devir Hızı = Net Satışlar / Maddi Duran Varlıklar (Net) \\
\hline Net Kâr / Aktif Toplam Oranı \\
\hline Net Kâr / Net Satışlar Oranı \\
\hline Faaliyet Kârı / Net Satışlar Oranı \\
\hline Brüt Satış Kârı / Net Satışlar Oranı \\
\hline Satılan Malın Maliyeti / Net Satışlar Oranı \\
\hline
\end{tabular}

Kaynak: http://www.tcmb.gov.tr, 2018.

Tablo 4'te verilen oranların sonuçları dikkate alınarak ayrıca eğilim yüzdeleri de hesaplanmıştır. Söz konusu karşılaştırmalar ve bu karşılaştırmalara ait grafik görüntüleri “stoklar/dönen varlıklar” oranından başlanarak sırasıyla aşağıda sunulmuştur.

Tablo 5. Stoklar / dönen varlıklar

\begin{tabular}{|c|c|c|c|c|c|c|}
\hline & \multicolumn{3}{|c|}{ Oranlar } & \multicolumn{3}{|c|}{ Ĕğilim Yüzdeleri } \\
\hline & 2014 & 2015 & 2016 & 2014 & 2015 & 2016 \\
\hline Tuğla İşletmesi & 0,32 & 0,42 & 0,20 & 100 & 129 & 61 \\
\hline İmalat, Küçük Ölçekli & 34,49 & 34,78 & 37,99 & 100 & 101 & 110 \\
\hline $\begin{array}{l}\text { Diğer Metalik Olmayan Mineral Ürünler } \\
\text { İmalatı, Küçük Firmalar }\end{array}$ & 34,97 & 34,80 & 36,10 & 100 & 100 & 103 \\
\hline Kilden İnşaat Malzemeleri İmalatı & 29,86 & 30,92 & 29,48 & 100 & 104 & 99 \\
\hline Tuğla İşletmesi & 0,32 & 0,42 & 0,20 & 100 & 129 & 61 \\
\hline İnşaat & 23,63 & 26,14 & 25,23 & 100 & 111 & 107 \\
\hline Bina İnşaatı & 36,28 & 39,34 & 39,25 & 100 & 108 & 108 \\
\hline
\end{tabular}



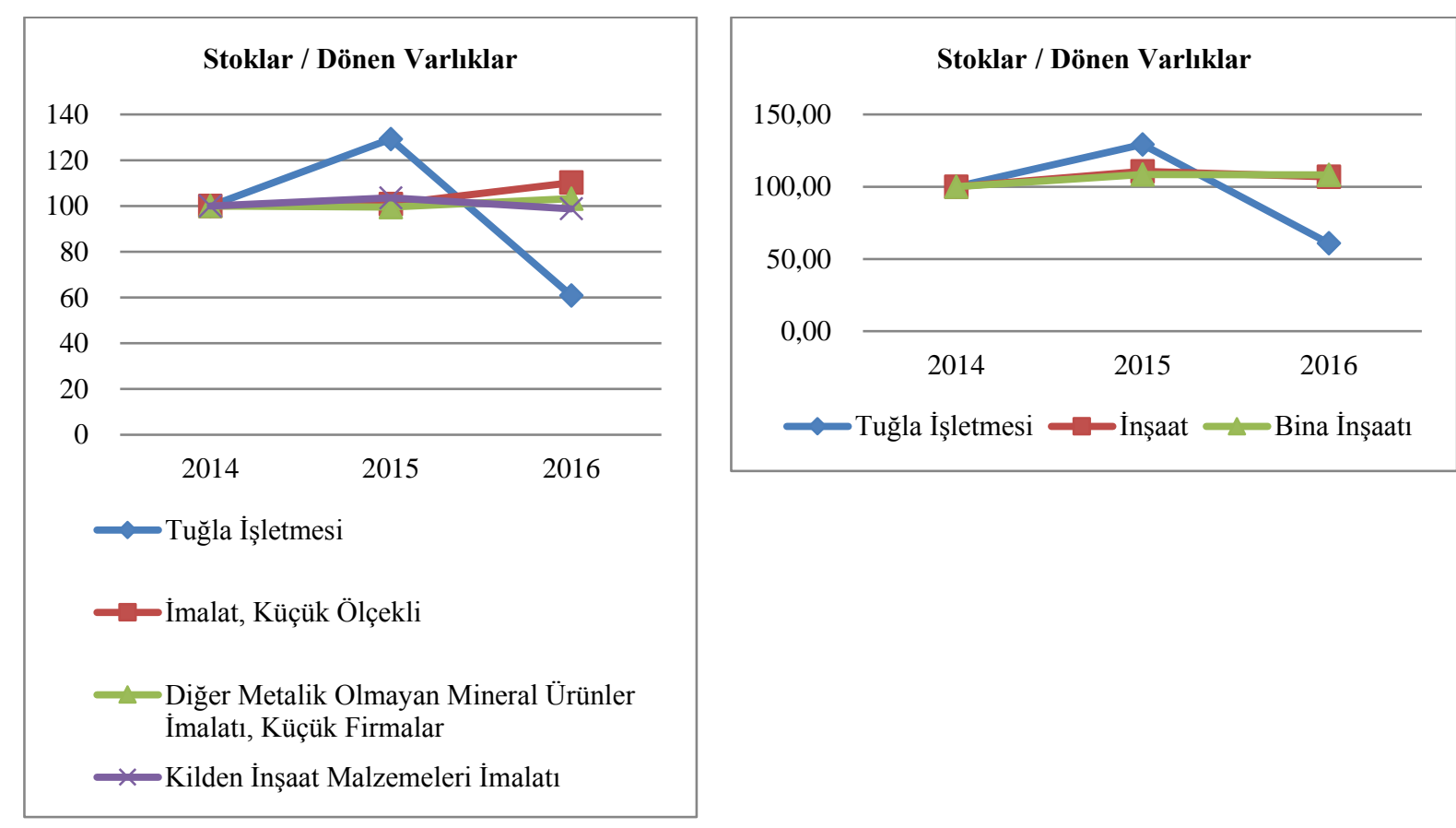

Şekil 1. Stoklar / dönen varlıklar

Stoklar/dönen varlıklar oranı açısından küçük ölçekli imalat işletmelerinin 2015 yılında durağan kaldığı, 2016 y1lında ise \%10 seviyesinde artış kaydettiği görülmektedir. Tuğla işletmesinin dâhil olduğu diğer metalik olmayan mineral ürünler imalatı yapan küçük işletmeler gurubu ve bu grup içerisinde kilden inşaat malzemesi üreten işletmelerin birbiri ile benzer şekilde durağan bir seyir izlediği görülmektedir. Tuğla işletmesinde ise bu sayılan gruplardan farklı olarak 2015 yılında artış, 2016 yılında ise büyük bir düşüş yaşanmıştır. Tuğla işletmelerinin müşterisi konumundaki inşaat sektörü ve bu grup içerisindeki bina inşaatı yapan firmalar da birbiri ile benzer şekilde 2015 y1lında düşük oranda artış kaydetmiş, 2016 yılında ise bina inşaatı sabit kalırken inşaat sektörü düşüş yaşamış olup bu durum, tuğla işletmesinde yaşanan artış ve düşüşe benzerlik göstermektedir.

Tablo 6. Alacak devir hızı

\begin{tabular}{|c|c|c|c|c|c|c|}
\hline & \multicolumn{3}{|c|}{ Oranlar } & \multicolumn{3}{|c|}{ Eğilim Yüzdeleri } \\
\hline & 2014 & 2015 & 2016 & 2014 & 2015 & 2016 \\
\hline Tuğla İșletmesi & 2,01 & 1,94 & 1,83 & 100 & 96 & 91 \\
\hline İmalat, Küçük Ölçekli & 3,14 & 2,85 & 2,60 & 100 & 91 & 83 \\
\hline $\begin{array}{l}\text { Diğer Metalik Olmayan Mineral Ürünler } \\
\text { İmalatı, Küçük Firmalar }\end{array}$ & 3,54 & 3,08 & 2,91 & 100 & 87 & 82 \\
\hline Kilden İnşaat Malzemeleri İmalatı & 1,73 & 1,80 & 1,47 & 100 & 104 & 85 \\
\hline Tuğla İşletmesi & 2,01 & 1,94 & 1,83 & 100 & 96 & 91 \\
\hline İnşaat & 2,62 & 1,84 & 2,15 & 100 & 70 & 82 \\
\hline Bina İnșaatı & 2,14 & 1,58 & 1,77 & 100 & 74 & 83 \\
\hline
\end{tabular}




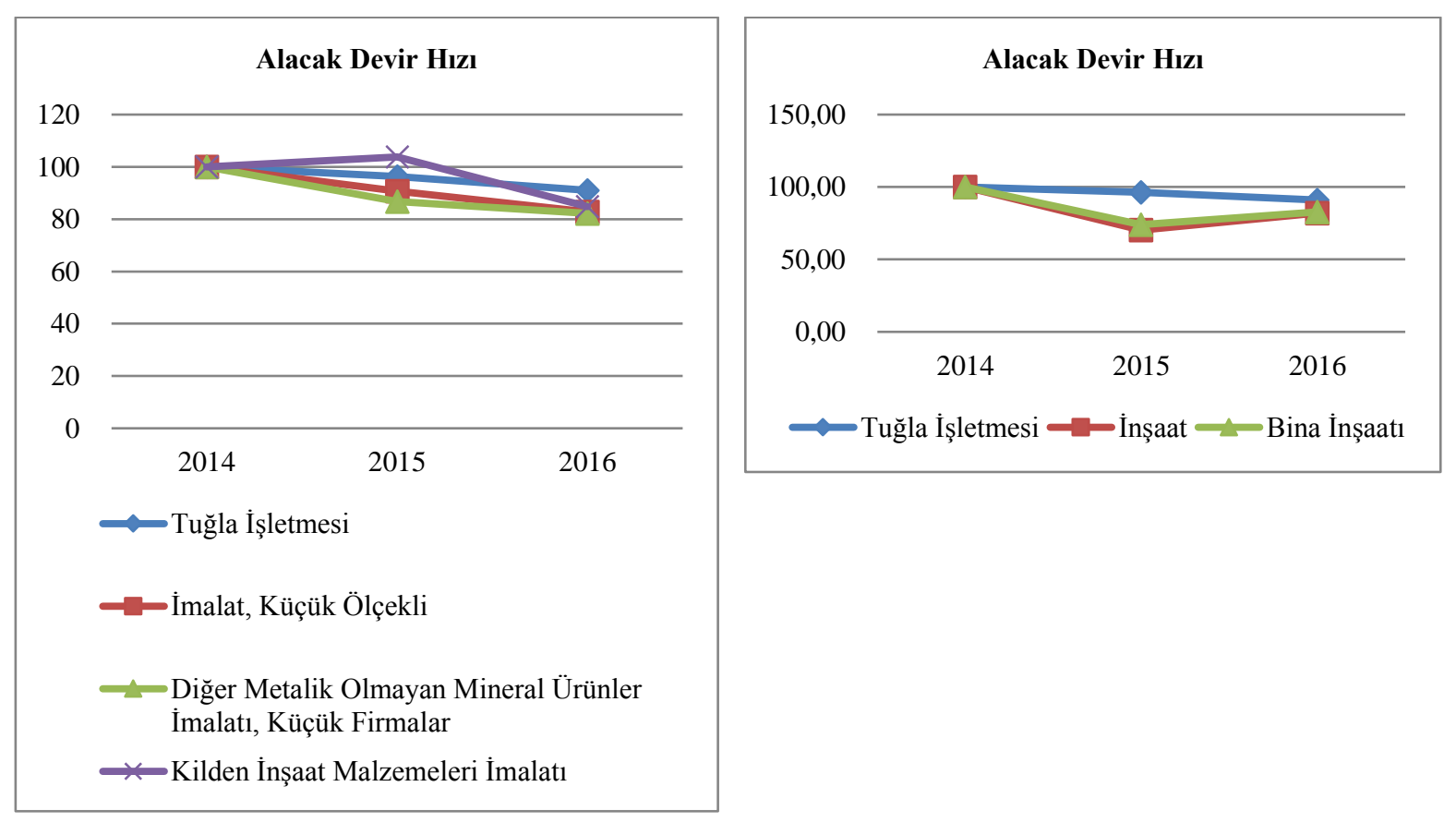

Şekil 2. Alacak devir hızı

Alacak devir hızı oranları küçük ölçekli imalat işletmelerinde ve diğer metalik olmayan mineral ürün imalatı yapan küçük ölçekli işletmelerde tuğla işletmesiyle benzer bir şekilde azalış gösterirken kilden inşaat malzemesi imalatı grubunda 2015 yılında artış yaşanmasına rağmen 2016 yılında diğerleri gibi azalış ortaya çıkmıştır. İnşaat ve bina inşaatında 2015 yılında büyük bir düşüş ortaya çıkarken 2016 yılında biraz kendini toparladığı söylenebilir. Tuğla işletmesinde ise 2015 yılında daha düşük bir azalış ortaya çıkmıştır; ancak 2016 yılında azalış devam etmiştir.

Tablo 7. Çalışma sermayesi devir hızı

\begin{tabular}{|c|c|c|c|c|c|c|}
\hline & \multicolumn{3}{|c|}{ Oranlar } & \multicolumn{3}{|c|}{ Eğilim Yüzdeleri } \\
\hline & 2014 & 2015 & 2016 & 2014 & 2015 & 2016 \\
\hline Tuğla İşletmesi & 1,27 & 1,03 & 1,38 & 100 & 81 & 109 \\
\hline İmalat, Küçük Ölçekli & 1,16 & 1,07 & 0,98 & 100 & 93 & 85 \\
\hline $\begin{array}{l}\text { Diğer Metalik Olmayan Mineral Ürünler } \\
\text { İmalatı, Küçük Firmalar }\end{array}$ & 1,43 & 1,22 & 1,12 & 100 & 86 & 79 \\
\hline Kilden İnşaat Malzemeleri İmalatı & 0,87 & 0,84 & 0,79 & 100 & 96 & 90 \\
\hline Tuğla İşletmesi & 1,27 & 1,03 & 1,38 & 100 & 81 & 109 \\
\hline İnşaat & 0,48 & 0,37 & 0,40 & 100 & 77 & 84 \\
\hline Bina İnşaatı & 0,40 & 0,29 & 0,36 & 100 & 73 & 88 \\
\hline
\end{tabular}



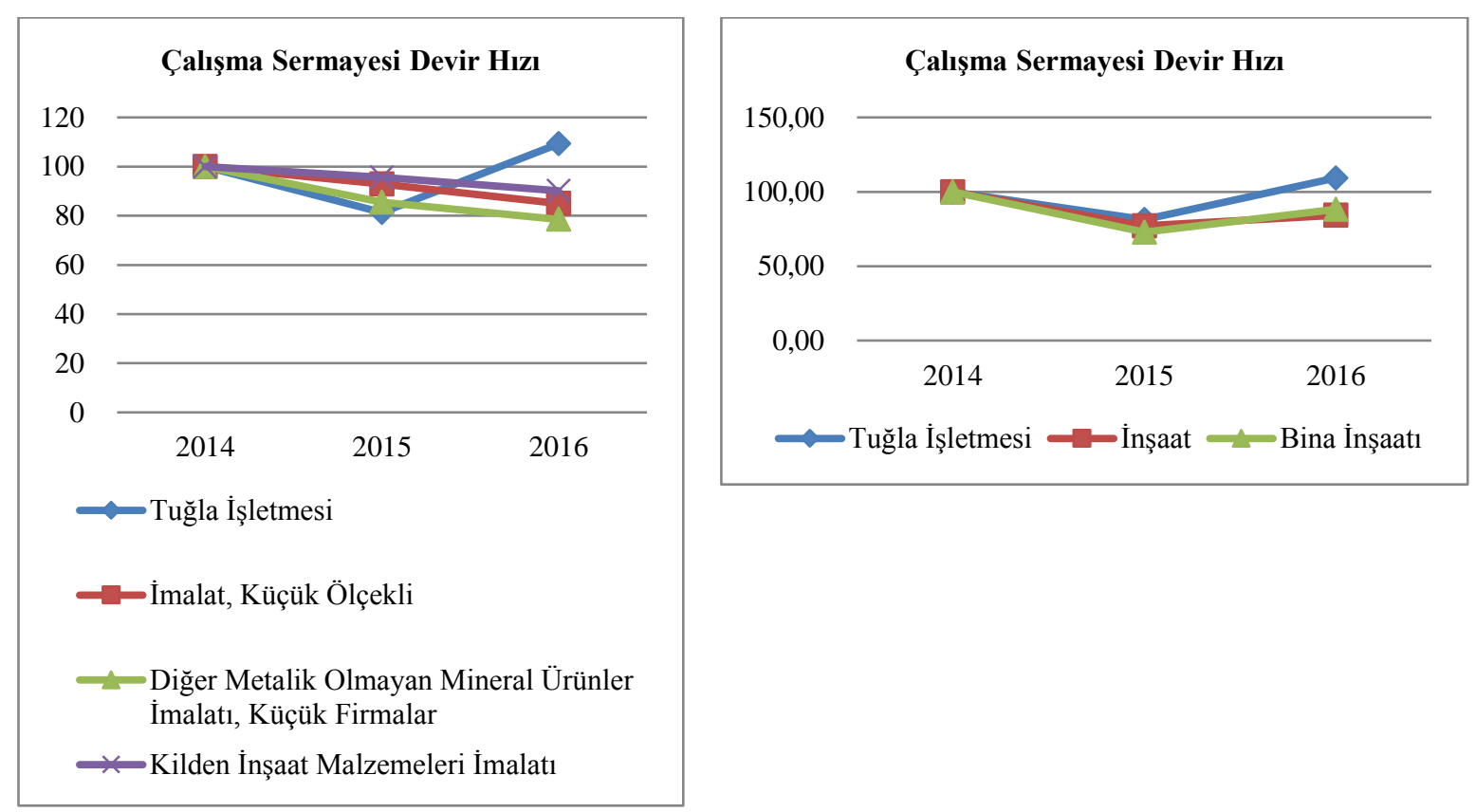

Şekil 3. Çalışma Sermayesi Devir Hızı

Çalışma sermayesi devir hızı açısından bakıldığında küçük ölçekli imalat işletmeleri, diğer metalik olmayan mineral ürünler imalatı yapan küçük ölçekli işletmeler ve kilden inşaat malzemesi imalatında 2015 yılında başlayan düşüş eğilimi 2016 y1lında da devam etmiştir. Buna karşılık tuğla işletmesinde 2015 yılında ortaya çıkan düşüşün 2016 y1lında yükselişe geçtiği görülmektedir. Tuğla işletmesi ile inşaat ve bina inşaatında 2015 yılında çalışma sermayesi devir hızında düşüş olmasına ve 2016 yılında her üçünde de artış olmasına rağmen tuğla işletmesinin görünümü çok daha olumlu bir seviyededir.

Tablo 8. Maddi duran varlık devir hızı

\begin{tabular}{|c|c|c|c|c|c|c|}
\hline & \multicolumn{3}{|c|}{ Oranlar } & \multicolumn{3}{|c|}{ Ĕğilim Yüzdeleri } \\
\hline & 2014 & 2015 & 2016 & 2014 & 2015 & 2016 \\
\hline Tuğla İşletmesi & 7,58 & 7,80 & 7,96 & 100 & 103 & 105 \\
\hline İmalat, Küçük Ölçekli & 2,46 & 2,21 & 1,96 & 100 & 90 & 80 \\
\hline $\begin{array}{l}\text { Diğer Metalik Olmayan Mineral Ürünler } \\
\text { İmalatı, Küçük Firmalar }\end{array}$ & 2,34 & 2,20 & 1,98 & 100 & 94 & 84 \\
\hline Kilden İnşaat Malzemeleri İmalatı & 0,94 & 0,94 & 0,82 & 100 & 101 & 87 \\
\hline Tuğla İşletmesi & 7,58 & 7,80 & 7,96 & 100 & 103 & 105 \\
\hline İnşaat & 1,59 & 1,13 & 1,25 & 100 & 71 & 78 \\
\hline Bina İnşaatı & 1,08 & 0,74 & 0,86 & 100 & 69 & 80 \\
\hline
\end{tabular}




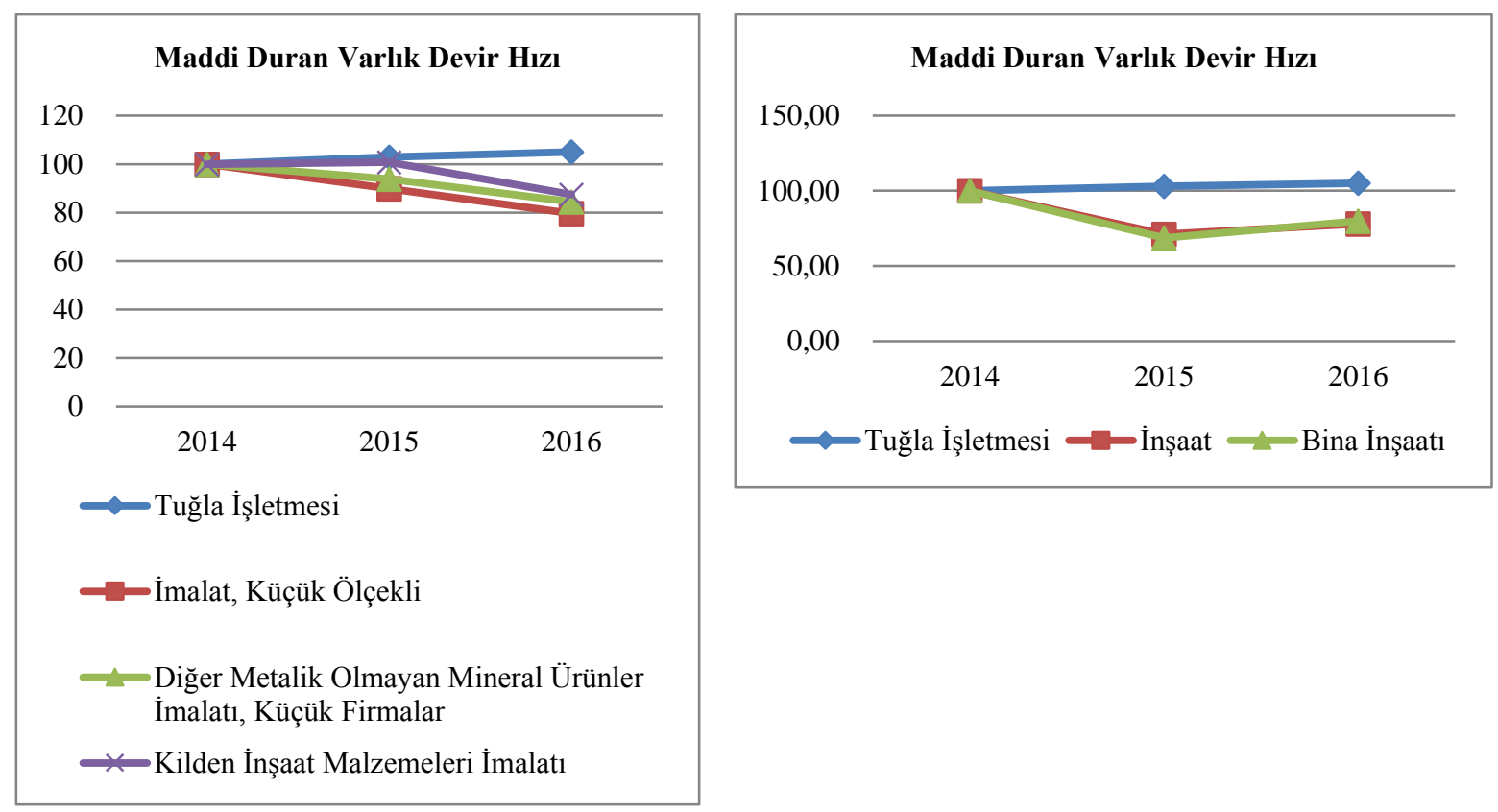

Şekil 4. Maddi duran varlık devir hızı

Maddi duran varlık devir hızının küçük ölçekli imalat ile diğer metalik olmayan mineral ürünler imalatı yapan küçük ölçekli işletmelerde azalış eğiliminde olduğu görülmektedir. Kilden inşaat malzemesi imalatında ise 2015 yılında seviye korunurken 2016 yılında düşüş ortaya çıkmıştır. Tuğla işletmesinde ise düşük seyirli bir artış ortaya koyulmuştur. İnşaat ve bina inşaatında ise 2015 yılındaki büyük düşüşün ardından 2016 yılında küçük bir artış ortaya çıktığı görülmektedir.

Tablo 9. Net kâr / aktif toplam

\begin{tabular}{|c|c|c|c|c|c|c|}
\hline & \multicolumn{3}{|c|}{ Oranlar } & \multicolumn{3}{|c|}{ Eğilim Yüzdeleri } \\
\hline & 2014 & 2015 & 2016 & 2014 & 2015 & 2016 \\
\hline Tuğla İşletmesi & 0,08 & 0,03 & 0,10 & 100 & 32 & 117 \\
\hline İmalat, Küçük Ölçekli & 0,55 & $-0,19$ & $-1,35$ & 100 & -35 & -247 \\
\hline $\begin{array}{l}\text { Diğer Metalik Olmayan Mineral Ürünler } \\
\text { İmalatı, Küçük Firmalar }\end{array}$ & 0,69 & 1,63 & $-0,27$ & 100 & 236 & -39 \\
\hline Kilden İnşaat Malzemeleri İmalatı & $-0,15$ & $-3,48$ & $-2,53$ & 100 & -2.263 & -1.643 \\
\hline Tuğla İşletmesi & 0,08 & 0,03 & 0,10 & 100 & 32 & 117 \\
\hline İnşaat & 2,89 & 0,71 & 0,69 & 100 & 24 & 24 \\
\hline Bina İnşaatı & 2,24 & $-0,30$ & $-1,18$ & 100 & -14 & -52 \\
\hline
\end{tabular}



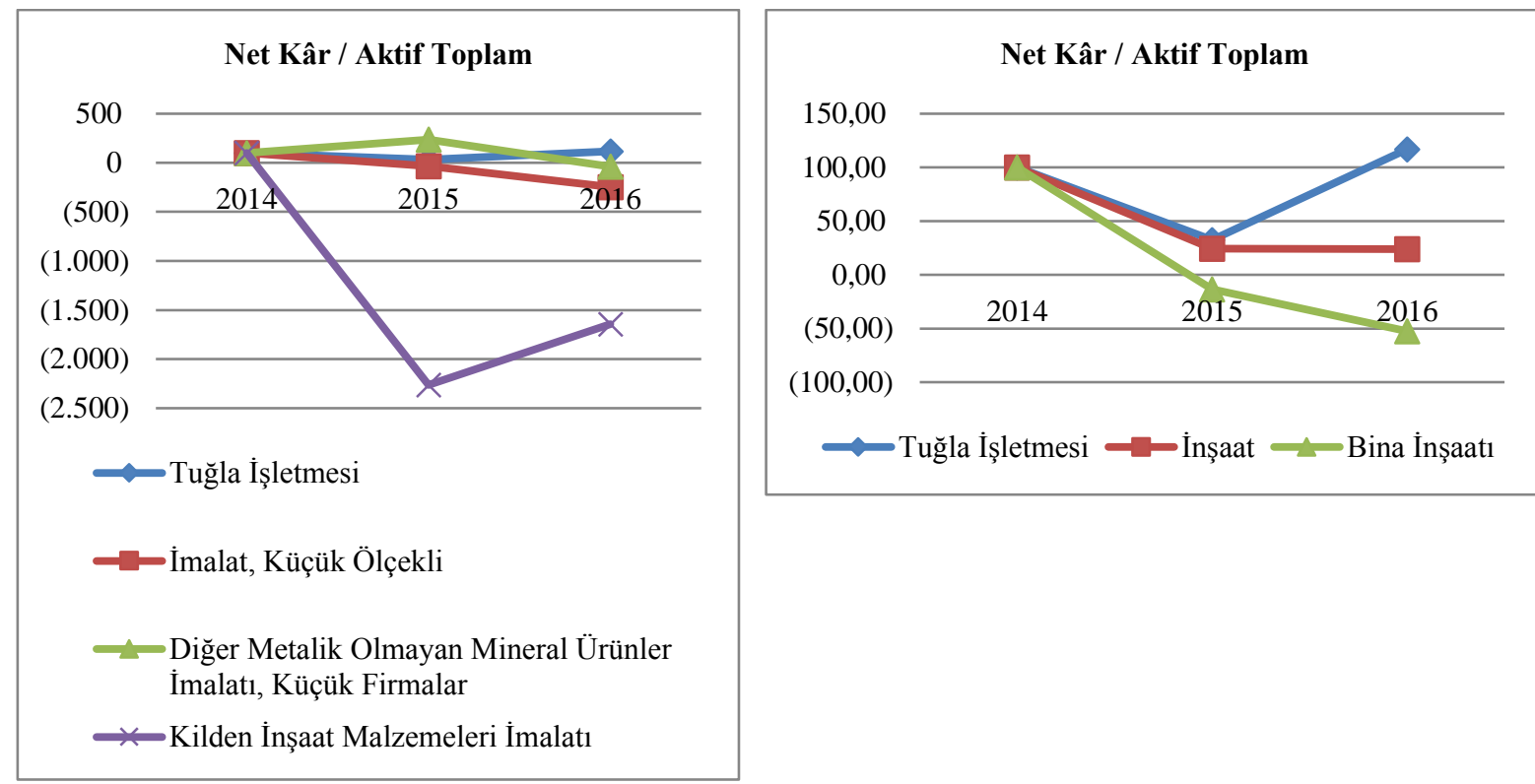

Şekil 5. Net kâr / aktif toplam

İşletme varlıkları karşısında elde edilen net kâra bakıldığında küçük ölçekli imalat işletmelerinde 2015 yılındaki büyük düşüşün ardından 2016 yılında çok daha büyük bir oranda azalış söz konusudur. Diğer metalik olmayan mineral ürünlerin imalatını yapan küçük ölçekli işletmelerde ise 2015 yılında oldukça yüksek oranda artış olmasına karşılık 2016 yılında büyük bir düşüş ortaya çıkmıştır. Kilden inşaat malzemeleri imalatında ise her üç yılda da zarar söz konusu olup 2015 yılında çok daha büyük oranda zararın etkisi görülmekteyken 2016 yılında bu etkinin azalış eğilimine girdiği söylenebilir. Bunlara karşılık tuğla işletmesinde 2015 yılında oran büyük bir azalış gösterirken 2016 yılında eski seviyenin biraz üzerine çıkıldığ1 söylenebilir. 2015 y1lında tuğla işletmesinde, inşaat sektöründe ve bina inşaatlarında bu oran büyük bir düşüş yaşarken en büyük azalma bina inşaatında gerçekleşmiştir. Ancak 2016 yılında tuğla işletmesinde eski seviyenin üzerine çıkılmasına karşılık inşaat sektörü 2015 yılındaki seviyeyi sürdürmüş, bina inşaatında ise oran daha da azalmıştır.

Tablo 10. Net kâr / net satışlar

\begin{tabular}{|c|c|c|c|c|c|c|}
\hline & \multicolumn{3}{|c|}{ Oranlar } & \multicolumn{3}{|c|}{ Ĕgilim Yüzdeleri } \\
\hline & 2014 & 2015 & 2016 & 2014 & 2015 & 2016 \\
\hline Tuğla İşletmesi & 0,08 & 0,03 & 0,08 & 100 & 38 & 102 \\
\hline İmalat, Küçük Ölçekli & 0,82 & $-0,32$ & $-2,50$ & 100 & -39 & -305 \\
\hline $\begin{array}{l}\text { Diğer Metalik Olmayan Mineral Ürünler } \\
\text { İmalatı, Küçük Firmalar }\end{array}$ & 0,82 & 2,19 & $-0,40$ & 100 & 268 & -49 \\
\hline Kilden İnşaat Malzemeleri İmalatı & $-0,41$ & $-9,04$ & $-8,12$ & 100 & -2.208 & -1.985 \\
\hline Tuğla İşletmesi & 0,08 & 0,03 & 0,08 & 100 & 38 & 102 \\
\hline İnşaat & 9,93 & 3,24 & 2,87 & 100 & 33 & 29 \\
\hline Bina İnşaatı & 8,89 & $-1,67$ & $-5,47$ & 100 & -19 & -62 \\
\hline
\end{tabular}



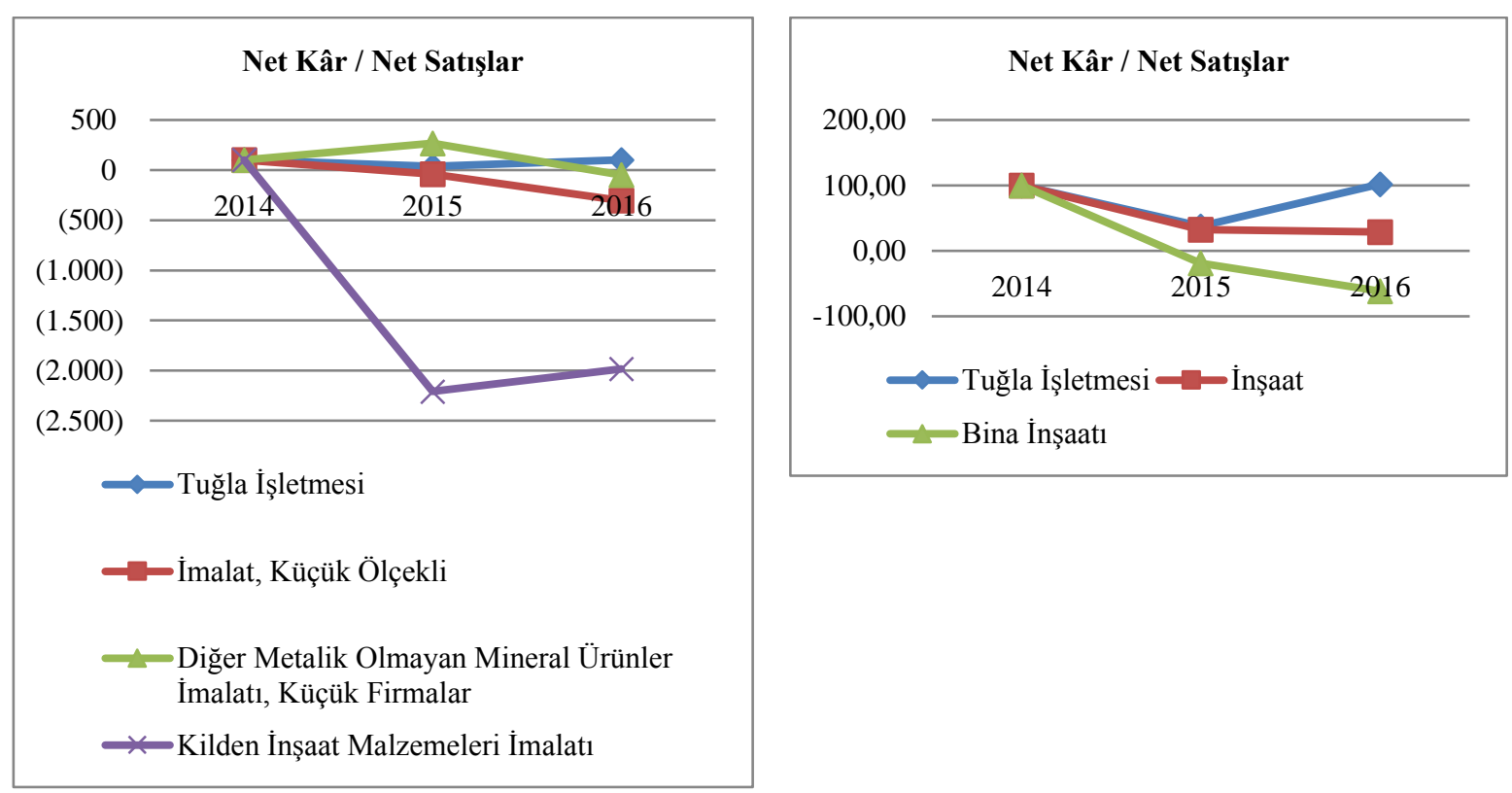

Şekil 6. Net kâr / net satışlar

Net satışlara karşılık elde edilen net kâra ait oranlar, net kâr/aktif toplam oranından elde edilen sonuçlara paralellik göstermekte olup karşılaştırma yapılan tüm unsurlarda büyük dalgalanmalar görülmektedir. Her ne kadar 2015 yılında tuğla işletmesine ait oranda büyük bir düşüş ortaya çıksa da 2016 yılında en iyi durumda tuğla işletmesinin olduğu görülmektedir.

Tablo 11. Faaliyet kârı / net satışlar

\begin{tabular}{|c|c|c|c|c|c|c|}
\hline & \multicolumn{3}{|c|}{ Oranlar } & \multicolumn{3}{|c|}{ Eğilim Yüzdeleri } \\
\hline & 2014 & 2015 & 2016 & 2014 & 2015 & 2016 \\
\hline Tuğla İşletmesi & 0,12 & 0,06 & 0,11 & 100 & 47 & 91 \\
\hline İmalat, Küçük Ölçekli & 6,30 & 7,03 & 7,01 & 100 & 112 & 111 \\
\hline $\begin{array}{l}\text { Diğer Metalik Olmayan Mineral Ürünler } \\
\text { İmalatı, Küçük Firmalar }\end{array}$ & 5,69 & 7,04 & 6,71 & 100 & 124 & 118 \\
\hline Kilden İnşaat Malzemeleri İmalat1 & 8,74 & 8,23 & 8,10 & 100 & 94 & 93 \\
\hline Tuğla İşletmesi & 0,12 & 0,06 & 0,11 & 100 & 47 & 91 \\
\hline İnşaat & 7,46 & 7,05 & 7,86 & 100 & 95 & 105 \\
\hline Bina İnşaatı & 8,41 & 8,04 & 6,79 & 100 & 96 & 81 \\
\hline
\end{tabular}



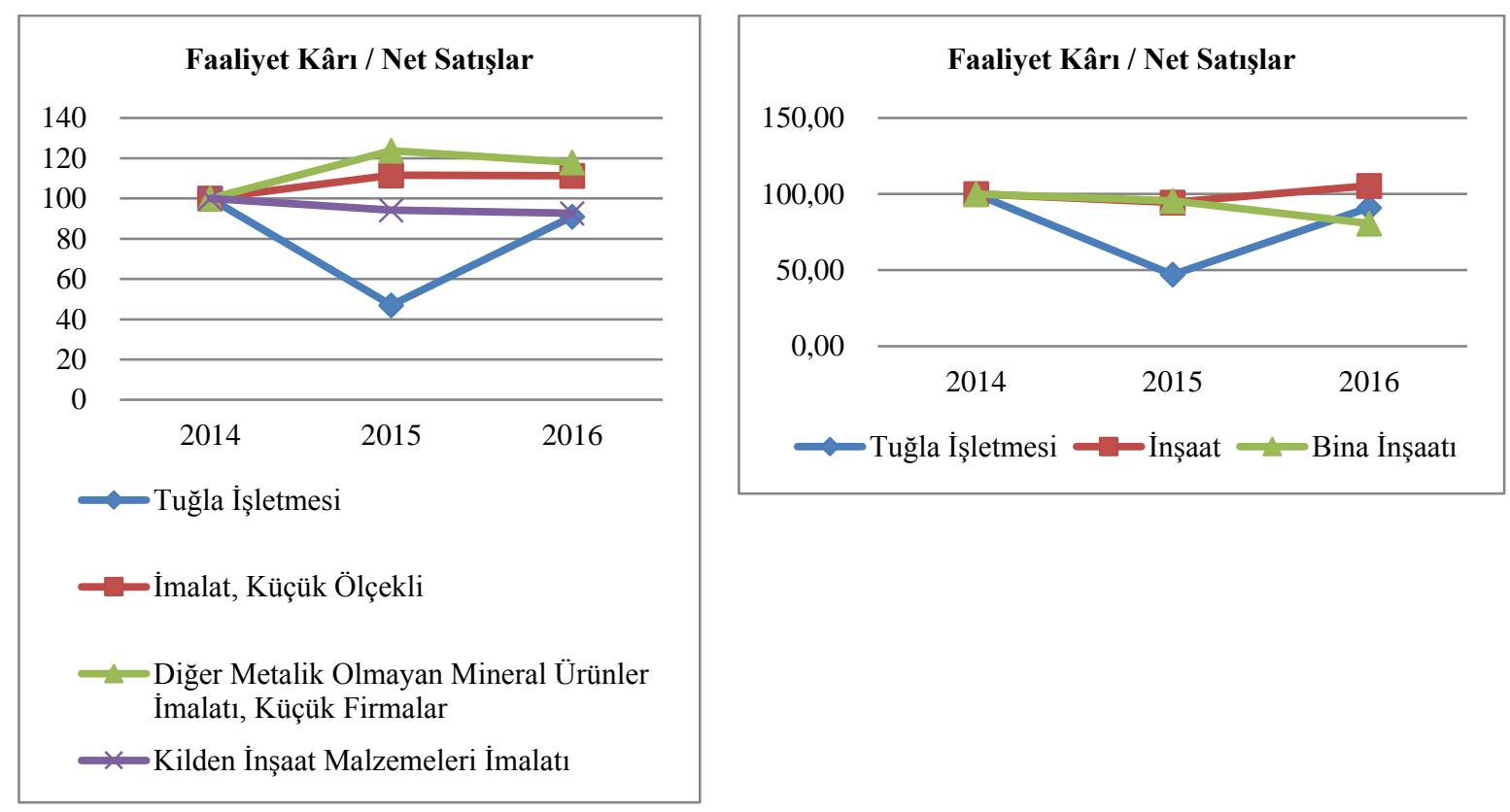

Şekil 7. Faaliyet kârı / net satışlar

Net satışlar karşılığında ne kadar faaliyet kârı elde edildiğine bakıldığında 2015 yılında küçük ölçekli imalat işletmesi ile diğer metalik olmayan mineral ürünler imalatı yapan küçük ölçekli işletmelerin yükseliş gösterdiği; ancak 2016 yılında bunların küçük bir düşüş yaşadıkları görülmektedir. Kilden inşaat malzemeleri imalatında her iki yılda da çok az düşüş gözlenmekte olup benzer durum bina inşaatı için de geçerlidir. İnşaat sektöründe ise 2015 yılındaki yüzde 5 seviyesindeki azalış 2016 yılında yüzde 5 artış olarak gerçekleşmiştir. Tuğla işletmesinde ise 2015 yılı, diğerleriyle kıyaslanınca en kötü göstergeye sahipken 2016 yılında toparlanma sürecine girildiği görülmektedir.

Tablo 12. Brüt satış kârı / net satışlar

\begin{tabular}{|c|c|c|c|c|c|c|}
\hline & \multicolumn{3}{|c|}{ Oranlar } & \multicolumn{3}{|c|}{ Eğilim Yüzdeleri } \\
\hline & 2014 & 2015 & 2016 & 2014 & 2015 & 2016 \\
\hline Tuğla İșletmesi & 0,14 & 0,07 & 0,14 & 100 & 53 & 101 \\
\hline İmalat, Küçük Ölçekli & 16,80 & 17,91 & 18,75 & 100 & 107 & 112 \\
\hline $\begin{array}{l}\text { Diğer Metalik Olmayan Mineral Ürünler } \\
\text { İmalatı, Küçük Firmalar }\end{array}$ & 16,05 & 17,83 & 17,74 & 100 & 111 & 111 \\
\hline Kilden İnşaat Malzemeleri İmalatı & 20,78 & 20,22 & 20,03 & 100 & 97 & 96 \\
\hline Tuğla İşletmesi & 0,14 & 0,07 & 0,14 & 100 & 53 & 101 \\
\hline İnşaat & 13,05 & 14,20 & 13,42 & 100 & 109 & 103 \\
\hline Bina İnşaatı & 15,63 & 17,28 & 13,73 & 100 & 111 & 88 \\
\hline
\end{tabular}



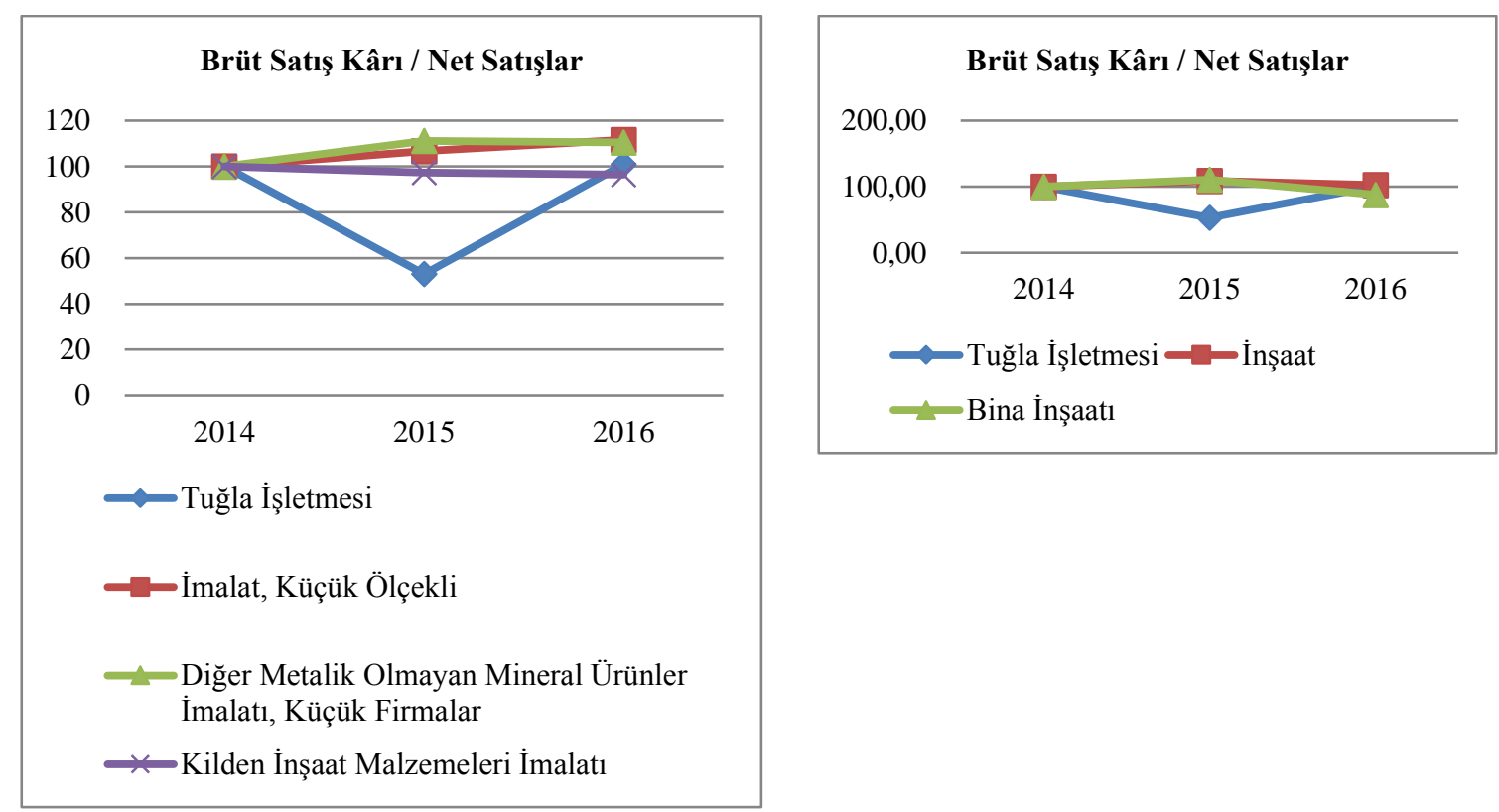

Şekil 8. Brüt satış kârı / net satışlar

Faaliyet kârı/net satışlar oranına benzer şekilde net satışlara karşılık elde edilen brüt satış kârında 2015 yılında tuğla işletmesi diğerlerinden oldukça farklı bir şekilde düşüş sergilemiş; ancak 2016 yılında eski seviyesine yeniden ulaşmıştır.

Tablo 13. Satılan malın maliyeti / net satışlar

\begin{tabular}{|c|c|c|c|c|c|c|}
\hline & \multicolumn{3}{|c|}{ Oranlar } & \multicolumn{3}{|c|}{ Ĕ̆ilim Yüzdeleri } \\
\hline & 2014 & 2015 & 2016 & 2014 & 2015 & 2016 \\
\hline Tuğla İșletmesi & 0,86 & 0,93 & 0,86 & 100 & 107 & 100 \\
\hline İmalat, Küçük Ölçekli & 83,20 & 82,09 & 81,25 & 100 & 99 & 98 \\
\hline $\begin{array}{l}\text { Diğer Metalik Olmayan Mineral Ürünler } \\
\text { İmalatı, Küçük Firmalar }\end{array}$ & 83,95 & 82,17 & 82,26 & 100 & 98 & 98 \\
\hline Kilden İnşaat Malzemeleri İmalatı & 79,22 & 79,78 & 79,97 & 101 & 101 & 101 \\
\hline Tuğla İşletmesi & 0,86 & 0,93 & 0,86 & 100 & 107 & 100 \\
\hline İnşaat & 86,95 & 85,80 & 86,58 & 100 & 99 & 100 \\
\hline Bina İnşaatı & 84,37 & 82,72 & 86,27 & 100 & 98 & 102 \\
\hline
\end{tabular}



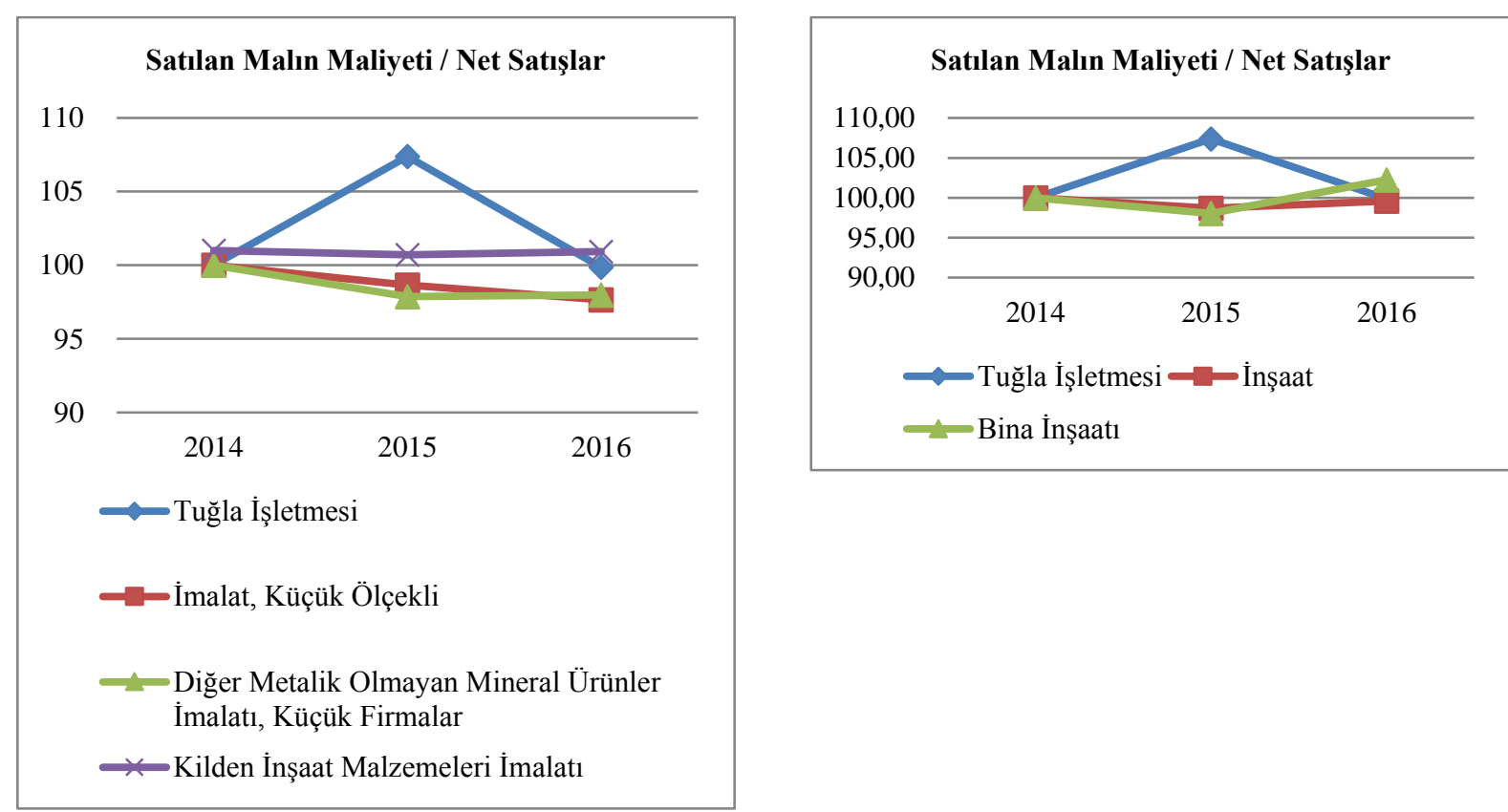

Şekil 9. Satılan malın maliyeti / net satışlar

İşletmenin gerçekleştirdiği satışlara ait satılan mamul maliyetlerinin tuğla işletmesinde 2015 yılında artış yaşamasına karşılık 2016 yılında eski seviyesine geri döndüğü görülmektedir. Karşılaştırma yapılan diğer tüm alanlarda ise küçük oranda artış veya azalışlar olmasına rağmen genel olarak aynı seviyeyi koruduğu görülmektedir.

Sektör, alt sektör ve firma gruplarıyla gerçekleştirilen karşılaştırmalar neticesinde tuğla üretim işletmesinde en dikkat çekici farklılıklar aşağıdaki gibi sıralanabilir:

- Stoklar / Dönen Varlıklar oranında 2015 yılındaki artış ile 2016 yılındaki düşüş,

- Çalışma Sermayesi Devir Hızında 2016 yılındaki artış,

- Maddi Duran Varlık Devir Hızının önceki seviyesini koruyabilmesi,

- Net Kâr / Aktif Toplam ile Net Kâr / Net Satışlar oranlarında inşaat sektörüne göre 2016 yılındaki artış,

- Faaliyet Kârı / Net Satışlar ile Brüt Satış Kârı / Net Satışlar oranlarında 2015 yılındaki düşüş ve bunlarla ilişkili şekilde

- Satılan Malın Maliyeti / Net Satışlar oranında 2015 yılındaki yükseliş. 


\section{SONUÇ}

İnşaat sektörü, imalat sektörünün önemli unsurlarından birini oluşturmaktadır ve inşaat sektöründe yaşanan gelişmeler, ülke ekonomisi içerisinde birçok sektörün doğrudan etkilenmesine yol açmaktadır. Tuğla sektörü de inşaat sektörünün temel girdilerinden biri olan tuğlanın üretimini gerçekleştirdiği için bu çalışmada bir işletmeye ait finansal veriler kullanılarak tuğla üretimiyle ilişkili sektörlerin karşılaştırması yapıllmıştır.

2014 yılına kıyasla 2015 ve 2016 yıllarındaki oranlara ait eğilimler incelenmiş ve tuğla işletmesinin özellikle çalışma sermayesi devir hızında ve net kâr/aktif toplam oranı ile brüt satış kârı/net satışlar oranında 2016 yılındaki artış; faaliyet kârı/net satışlar oranı ile brüt satış kârı/net satışlar oranında 2015 yılındaki düşüş; stoklar/dönen varlıklar oranında 2015 yılındaki artışa karşılık 2016 yılındaki düşüş; satılan malın maliyeti/net satışlar oranında 2015 yılındaki yükseliş, karşılaştırılan diğer sektör oranlarına göre dikkat çekmektedir.

Bu çalışmada tuğla üretim işletmesine ait oranlar ile tuğlanın kullanıldığı sektörler ve yine tuğlanın içerisinde bulunduğu sektöre ait oranlar dikkate alınarak, belirlenen yıllardaki bazı finansal oranlar karşılaştırılmış olup bundan sonraki çalışmalarda birden fazla tuğla işletmesinin dahil edilmesiyle kapsamın genişletilmesi, tuğla sektörü ve inşaat sektörünün finansal durumunu ortaya koymak açısından yararlı olacaktır.

\section{REFERENCES / KAYNAKLAR}

Akbulut, R. \& Rençber, Ö.F. (2015). BİST’te imalat sektöründeki işletmelerin finansal performansları üzerine bir araştırma. Muhasebe ve Finansman Dergisi, (65), 117-136.

Akın, F. \& Ece, N. (2013). İMKB'de işlem gören sigorta şirketlerinin 2006-2010 dönemi finansal performanslarının analizi. Muhasebe ve Finansman Dergisi, (57), 89-106.

Akyüz, Y., Bozdoğan, T. \& Hantekin, E. (2011). Topsis yöntemiyle finansal performansın değerlendirilmesi ve bir uygulama. Afyon Kocatepe Üniversitesi, I.I.B.F. Dergisi, 3(1), 73-92.

Altaş, D. \& Giray, S. (2005). Mali başarısızlığın çok değişkenli istatistiksel yöntemlerle belirlenmesi: tekstil sektörü örneği. Anadolu Üniversitesi Sosyal Bilimler Dergisi, 5(2), 13-28.

Demir, V. \& Çelik, İ. (2015). Türk ihracatçılarının mali tablo analizleri: kriz sonrası döneme ilişkin sektörel karşılaştırma. Muhasebe ve Denetime Bakış, 15(46), 53-80.

Dumanoğlu, S. \& Ergül, N. (2010). İMKB'de işlem gören teknoloji şirketlerinin mali performans ölçümü. Muhasebe ve Finansman Dergisi, (48), 101-111.

Ersöz, M. (2017). Kamu kurumlarında mali tablo analiz yöntemlerinin uygulanabilirliği. Saylştay Dergisi, (105), $1-40$ 
Gökçen, G. (2004). Enflasyonun mali tablolar analizine etkileri. Mali Çözüm, (69), 14-25.

Hacıevliyagil, N. \& Şit, A. (2016). İmalat Sanayi alt sektörlerinde sektör farklılıklarının finansal oranlar açısından karşılaştırılması. Çankırı Karatekin Üniversitesi Sosyal Bilimler Enstitüsü Dergisi, 7(1), 107-122.

İltaş, Y. (2016). Türkiye Cumhuriyet Merkez Bankası sektör bilançolarını kullanarak işletme sermayesi gereksinimini etkileyen değişkenler üzerine bir analiz: 1996-2013. Erciyes Üniversitesi İIBF Dergisi, (48), 123143.

İskenderoğlu, Ö., Karadeniz, E. \& Ayyıldız, N. (2015). Enerji sektörünün finansal analizi: Türkiye ve Avrupa enerji sektörü karşılaştırması. İşletme ve İktisat Çalışmaları Dergisi, 3(3), 86-97.

Karadeniz, E., Dalak, S., Beyazgül, M. \& Günay, F. (2016). Konaklama ve yiyecek hizmetleri alt sektöründeki küçük, orta ve büyük ölçekli işletmelerin finansal performansının karşılaştırmalı tablolar analizi tekniği ile incelenmesi. Muhasebe Bilim Dünyası Dergisi, 18(3), 631-657.

Karadeniz, E., Kahiloğulları, S. \& Kılıç, E. (2015). Karayolları yolcu taşımacılığı işletmelerinin finansal analizi: Türkiye Cumhuriyet Merkez Bankası sektör bilançolarında bir araştırma. Muhasebe ve Denetime Bakış, 15(46), 81-96.

Karadeniz, E., Koşan, L. \& Kahiloğulları, S. (2014). Borsa İstanbul'da işlem gören spor şirketlerinin finansal performansının oran yöntemiyle analizi. Ç. U. Sosyal Bilimler Enstitüsü Dergisi, 23(2), 129-144.

Öğünç, H. (2018). Gıda ve tekstil sektörlerinin karşılaştırmalı finansal analizi (2014-2016 Dönemi). Bucak Işsletme Fakültesi Dergisi, 1(1), 53-70.

Özer, Ö. (2012). Mali tablolar analizi: Bir hastane örneği. Gümüşhane Üniversitesi Sosyal Bilimler Elektronik Dergisi, (6), 183-199.

Özgülbaş, N., Koyuncugil, A.S., Duman, R. \& Hatipoğlu, B. (2008). Özel hastane sektörünün finansal değerlendirmesi. Muhasebe ve Finansman Dergisi, (40), 120-131.

Özolgun, H. (2017). Karşılaştırmalı mali tablolar analizi. Journal of Emerging Economies and Policy, 2(1), 5562.

Selimoğlu, S. \& Orhan, A. (2015). Finansal başarısızlığın oran analizi ve diskriminant analizi kullanılarak ölçümlenmesi: BİST'de işlem gören dokuma, giyim eşyası ve deri işletmeleri üzerine bir araştırma. Muhasebe ve Finansman Dergisi, (66), 21-40.

Uyar, A. \& Okumuş, E. (2010). Finansal oranlar aracılığgıla küresel ekonomik krizin üretim şirketlerine etkilerinin analizi: İMKB'de bir uygulama. Muhasebe ve Finansman Dergisi, (46), 146-156.

Yurdakul, M. \& İç, Y.T. (2003). Türk otomotiv firmalarının performans ölçümü ve analizine yönelik topsis yöntemini kullanan bir örnek çalışma. Gazi Üniversitesi Mühendislik Mimarlık Fakültesi Dergisi, 18(1), 1-18.

http://www.tcmb.gov.tr/wps/wcm/connect/TR/TCMB+TR/Main+Menu/Istatistikler/Reel+Sektor+Istatistikleri/S ektor+ Bilancolari, Erişim tarihi: 15.12.2018.

http://www3.tcmb.gov.tr/sektor/2017/Raporlar/sunus.pdf, Erişim tarihi: 15.12.2018. 